\section{ORIGINAL ARTICLE}

AFRICAN JOURNAL OF CLINICAL AND EXPERIMENTAL MICROBIOLOGY AJCEM/201179/21203

COPYRIGHT 2012

AFR. J. CLN. EXPER. MICROBIOL 13(2): 84-89 http://dx.doi.org/10.4314/ajcem.v13i2.5
MAY 2012 ISBN 1595-689X VOL 13(2) -http://www.ajol.info/journals/ajcem

\title{
COMPARISON OF DERMATOPHYTES AND OTHER AGENTS OF HUMAN DERMATITIS BETWEEN MALES AND FEMALES IN JOS, PLATEAU STATE, NIGERIA
}

${ }^{* 1}$ Chuku Aleruchi, ${ }^{1}$ Makinde Adesoji.A, ${ }^{2}$ Ta'ama Louisa, ${ }^{1}$ Dalis James, ${ }^{1}$ Shaibu Samson.J and ${ }^{3}$ Irokanulo Emenike.A.O. ${ }^{1}$ Dermatophilosis Research Center, National Veterinary Research Institute, Vom. Plateau State, Nigeria. ${ }^{2}$ National Veterinary Research Institute, Zonal Laboratory, Calabar. ${ }^{3}$ Bacterial Vaccine Production, National Veterinary Research Institute, Vom. Plateau State, Nigeria

*Correspondence: Dr. Chuku, Aleruchi. Dermatophilosis Research Center, Bacterial Research Department, National Veterinary Research Institute Vom, Plateau State. Nigeria. Email: aleruchichuku@yahoo.com

\begin{abstract}
Dermatophytes are a group of three genera of fungi namely Microsporum spp, Trichophyton spp and Epidermophyton spp that commonly cause infections of the skin, hair and nails due to their ability to utilize keratin in both man and animals. Dermatophytes and other agents of human dermatitis are believed to have gender predisposition because of the anatomical and physiological nature of these genders. A study was undertaken to compare the distribution of dermatophytes and other agents of human dermatitis in patients who visited the Dermatophilosis Research Laboratory, National Veterinary Research Institute, Vom, Plateau State of Nigeria. A total of 1551 patients were involved in this study from 2003 to 2007; 823 of whom were males and 728 females. Samples collected were skin scrapping, nails, hair and pus exudates. They were processed according to standard procedures. Nine hundred and thirty two $(60 \%)$ were positive for dermatophytes and other agents. Sporothrix schenckii (138 (12.4\%)), Aspergillus flavus (128 (11.5\%)), and Trichophyton mentagrophytes (112 (10.1\%)), Mucor sp (105 (9.5\%)) were the most commonly isolated fungi. Aspergillus flavus occurred more in males (74 (6.7\%)) while Sporothrix schenckii was more in females $(71(6.4 \%))$. More isolation was made from the head in males (185 $(19.8 \%))$ while in females more isolation was made from their limbs (150 (16.1\%)). Males generally were more affected with skin infections than females.
\end{abstract}

\section{INTRODUCTION}

Dermatophytes are a group of three genera of fungi namely Microsporum spp, Trichophyton spp and Epidermophyton spp. They commonly cause infections of the skin, hair and nails due to their ability to utilize keratin in both man and animals. They colonize the keratin tissues which results in inflammation caused by host response to metabolic by-products. Occasionally they invade the subcutaneous tissues, resulting in kerion development (1). Dermatophytes are transmitted by either direct contact with infected host (human or animal) or by direct or indirect contact with infected exfoliated skin or hair in combs, hair brushes, clothing, furniture, public seats, caps, bed linens, towels, and hotel rugs. Approximately $20 \%$ of human infections in urban areas are of animal origin while about $80 \%$ of human infections in rural areas are of animal origin (2).

The dermatophytes are classified as being anthropophilic, zoophilic or geophilic according to their normal habitat. Anthropophilic dermatophytes are those restricted to human hosts and produce a mild, chronic inflammation, zoophilic organisms are found primarily in animals and cause marked inflammatory reactions in humans who have contact with infected cats, dogs, cattle, horses, birds, or other animals. This is followed by a rapid termination of the infection. The geophilic species are usually recovered from the soil but occasionally infect humans and animals. They cause a marked inflammatory reaction, which limits the spread of the infection and may lead to a spontaneous cure but may also leave scars (3).

Dermatophytes and other agents of human dermatitis are believed to have gender predisposition because of the anatomical and physiological nature of these gender. There has also been several research works and resulting publications on the incidences of skin disease as it relates to geographical locations $(4,5$ and $6)$, to the old and sick (7), age groups (8), and occupational groups (9). Most of the studies that have been carried out here in Nigeria have concentrated on children with skin infection (10 and 11). Although Ta'ama et al, (12) looked at the general distribution of dermatophytes in skin lesions among males and females, there has not been much investigation in the aspect of comparing the skin infections that occur in males and females, the organism most prevalent in this infections or the area of the male and female skin most prone to this infections. Knowledge of these occurrences will greatly improve and prevent the high incidence of skin infections in males and females. It is based on these that this study is focused on the comparison of dermatophytes and other agents of human dermatitis between males and females in Jos, Plateau State of Nigeria. 


\section{MATERIALS AND METHODS}

A total number of 1551 patients visited the Dermatophilosis Research Laboratory, National Veterinary Research Institute, Vom in Jos, Plateau State, Nigeria between 2003 to 2007 with various complaints of skin infections. This was made up of 823 males and 728 females. The consent of the patients was obtained to use their samples for study.

\section{Sample collection and processing}

Samples from patients were collected from infected sites of the individuals and this was done by soaking cotton wool in $70 \%$ alcohol and swabbing the infected site to disinfect it. Skin scales, nails or hair was scraped using a sterile scalpel blade into clean paper. The pus exudates were collected into a sterile universal bottle. All specimens were labeled properly (name, age, and sex). The collected samples, (the hair and nails were first macerated) were processed by performing an initial wet mount preparation in $20 \%$ $\mathrm{KOH}$ (Potassium Hydroxide) for direct microscopy as described by (13). Afterwards the samples were seeded into Sabouraud dextrose agar containing chloramphenicol at $16 \mathrm{ug} / \mathrm{ml}$ using a straight inoculating wire and incubated at room temperature for three to four weeks. The pus was streaked aseptically in blood agar and incubated at $37^{\circ} \mathrm{C}$ for 24 hours. Gram stain was performed on the resultant culture and viewed using $x 100$ objective. Subsequent bacteria identification was performed to identify the culture. The fungi cultures were identified by their colonial morphology and tease mount method (14).

\section{RESULTS}

The results of the study revealed that out of the 1551 patients involved in this study, there were isolations of dermatophytes and other agents of dermatitis from $932(60 \%)$ of the samples collected. Table 1 indicates the array and number of dermatophytes and other agents isolated over the period 2003-2007.

\section{TABLE 1: DERMATOPHYTES AND OTHER AGENTS OF HUMAN DERMATITIS ISOLATED OVER A FIVE YEAR PERIOD.}

\begin{tabular}{|c|c|c|c|c|c|c|}
\hline Isolated Organisms & 2003 & 2004 & 2005 & 2006 & 2007 & Total \\
\hline Trichophyton tonsurans & 7 & - & 7 & 3 & 8 & 25 \\
\hline Trichophyton rubrum & 2 & 3 & 4 & 6 & 1 & 16 \\
\hline Trichophyton mentagrophytes & 4 & - & 34 & 63 & 11 & 112 \\
\hline Trichophyton violaesum & 4 & - & 3 & 21 & - & 28 \\
\hline Trichophyton verrucosum & - & - & 6 & 6 & 1 & 13 \\
\hline Trichophyton sp & 12 & 5 & 2 & 6 & 5 & 30 \\
\hline Aspergillus fumigates & 5 & 14 & 26 & 28 & 15 & 88 \\
\hline Aspergillus flavus & 31 & 32 & 30 & 2 & 32 & 128 \\
\hline Aspergillus niger & - & 9 & 11 & 25 & 33 & 80 \\
\hline Aspergillus sp & - & 1 & 5 & 1 & 5 & 12 \\
\hline Bipolaris $s p$ & 21 & 11 & 6 & 1 & - & 37 \\
\hline Penicillium sp & 16 & 17 & 5 & 1 & 3 & 42 \\
\hline Mucorsp & 18 & 30 & 24 & 8 & 25 & 105 \\
\hline Rhizopus sp & 11 & 11 & 19 & 4 & 13 & 57 \\
\hline Sporothrix schenckii & 40 & 46 & 15 & 4 & 34 & 138 \\
\hline Microsporum audouinii & 3 & - & 1 & 2 & 3 & 9 \\
\hline Staphylococcus aureus & 4 & 18 & 15 & 3 & 15 & 55 \\
\hline Geotricum sp & 2 & - & - & - & - & 2 \\
\hline Fusarium sp & 6 & 9 & 2 & - & - & 17 \\
\hline Scopulariopsis sp & 5 & 10 & - & - & - & 15 \\
\hline Clostridium & - & - & - & - & 6 & 6 \\
\hline Blastomyces dermatolides & 4 & 4 & 6 & 1 & 2 & 17 \\
\hline Curvularia sp & 7 & - & 3 & 4 & 4 & 19 \\
\hline Cladosporium & - & - & - & 2 & 7 & 9 \\
\hline Candida albicans & 12 & 9 & 2 & 5 & 8 & 36 \\
\hline Phialophora vemucosa & - & - & - & 2 & 2 & 5 \\
\hline Epidermtophyton floccosium & 2 & 1 & 4 & - & - & 7 \\
\hline Coccidioides immitis & - & - & - & 2 & - & 2 \\
\hline
\end{tabular}

The Prevalence of dermatophytes and other agents of human dermatitis in males and females from 2003 to 2007 are shown in Table 2. It states that Aspergillus flavus had the highest occurrence in males within the period of study while Sporothrix schenckii had the highest in females.
Table 3 shows the total number of males and females that attended the dermatophilosis research laboratory for each of the year and the number of positive isolations as well as the percentage isolations. It revealed that more males than females had complaints of skin infection. 
Table 4 shows an array of dermatophytes and other agents of human dermatitis isolated based on anatomical position in males and females. This revealed that males had more infection occurring on their heads while the females, had more infections occurring on their limbs.

TABLE 2: PREVALENCE OF DERMATOPHYTES AND OTHER AGENTS OF DERMATITIS ISOLATES IN MALES AND FEMALES FROM 2003-2007

\begin{tabular}{|c|c|c|}
\hline Isolated Organisms & Males & Females \\
\hline Trichophyton tonsurans & 13 & 12 \\
\hline Trichophyton rubrum & 10 & 6 \\
\hline Trichophyton mentagrophytes & 57 & 55 \\
\hline Trichophyton violaecum & 18 & 10 \\
\hline Trichophyton verrucosum & 6 & 9 \\
\hline Trichophyton sp & 17 & 13 \\
\hline Aspergillus fumigates & 54 & 34 \\
\hline Aspergillus flavus & 74 & 49 \\
\hline Aspergillus niger & 42 & 38 \\
\hline Aspergillus sp & 6 & 6 \\
\hline Bipolaris $s p$ & 19 & 18 \\
\hline Penicillium $s p$ & 26 & 16 \\
\hline Mucor $s p$ & 60 & 45 \\
\hline Rhizopus sp & 27 & 30 \\
\hline Sporothricum schenckii & 67 & 71 \\
\hline Microsporum audouinii & 3 & 6 \\
\hline Staphylococcus aureus & 36 & 19 \\
\hline Geotricum $s p$ & 1 & 1 \\
\hline Fusarium $s p$ & 12 & 6 \\
\hline Scopulariopsis $s p$ & 9 & 6 \\
\hline Clostridium $s p$ & 2 & 4 \\
\hline Blastomyces dermatitides & 10 & 7 \\
\hline Curvularia $s p$ & 10 & 9 \\
\hline Cladosporium $s p$ & 5 & 4 \\
\hline Candida albicans & 18 & 18 \\
\hline Phialophora vemucosa & 2 & 4 \\
\hline Epidermtophyton floccosium & 4 & 3 \\
\hline Coccidioides immitis & - & 3 \\
\hline
\end{tabular}

\begin{tabular}{|c|c|c|c|c|c|c|}
\hline \multirow[t]{2}{*}{ Year } & \multicolumn{3}{|c|}{ Males } & \multicolumn{3}{|c|}{ Females } \\
\hline & $\begin{array}{l}\text { Number on } \\
\text { roll }\end{array}$ & $\begin{array}{l}\text { Number of } \\
\text { +ve Isolation }\end{array}$ & $\begin{array}{l}\% \text { of }+v e \\
\text { Isolation }\end{array}$ & $\begin{array}{l}\text { Number on } \\
\text { roll }\end{array}$ & $\begin{array}{l}\text { Number of } \\
\text { +ve Isolation }\end{array}$ & $\begin{array}{l}\% \text { of }+v e \\
\text { Isolation }\end{array}$ \\
\hline 2003 & 164 & 109 & $20.9 \%$ & 114 & 70 & $17.03 \%$ \\
\hline 2004 & 206 & 111 & $21.3 \%$ & 150 & 70 & $17.03 \%$ \\
\hline 2005 & 164 & 103 & $19.8 \%$ & 195 & 99 & $24.09 \%$ \\
\hline 2007 & 163 & 121 & $23.2 \%$ & 127 & 84 & $20.44 \%$ \\
\hline Total & 823 & 521 & $100 \%$ & 728 & 411 & $100 \%$ \\
\hline
\end{tabular}


TABLE 4: FREQUENCY OF INFECTION IN THE ANATOMY OF MALES AND FEMALES FROM 2003 TO 2007

\begin{tabular}{lllllll}
\hline & \multicolumn{5}{c}{ Area of the body } \\
\cline { 2 - 7 } Sex & $\begin{array}{l}\text { General (all } \\
\text { over the } \\
\text { body) }\end{array}$ & $\begin{array}{l}\text { Limbs } \\
\text { (hands \& }\end{array}$ & $\begin{array}{l}\text { Head } \\
\text { (head, face \& } \\
\text { legs) }\end{array}$ & $\begin{array}{l}\text { Trunk } \\
\text { (shoulder to } \\
\text { buttocks) }\end{array}$ & $\begin{array}{l}\text { Folds } \\
\text { (armpit/knee) }\end{array}$ \\
Male & 90 & 176 & 185 & 61 & 5 & Nails \\
(toe \& \\
Female
\end{tabular}

\section{DISCUSSION}

The result obtained from this study has revealed a wide range of dermatophytes and other agents of human dermatitis that occur in both males and females. Two zoophilic species of dermatophytes, $T$. mentagrophytes and T. verrucosum, which are known to be fundamentally pathogens but sometimes cause disease in man, were isolated from this study. Anthropophilic species of dermatophytes T. rubrum, T. tonsurans and M. audouinii, which are mainly human pathogens but occasionally infect animals, were also isolated as well as other mould fungi from both sexes. This suggests that prevailing endemic pathogens among different species of living things have the ability to change with time in respect to the existing living and hygiene conditions.

In this study, more males, that is 521 out of 823 which gives a $63.3 \%$, had positive isolation of dermatophytes and other fungi more than the females which had 411 positive isolations out of 728 , giving a $56.5 \%$ of positive isolation. This could be as a result of the male skin which unlike the female skin has larger pores, a richer blood supply, and more active sebaceous glands. This means that the male skin is more prone to sweating and tends to be on the oilier side and as a result, male skin is, in fact, dirtier than female skin (15). The differing activities performed by most males and females in terms of the kind of jobs they do, period of exposure to the elements of weather and the care and attention given to the skin is also a contributing factor to the result gotten. Field and laboratory studies have linked this increased susceptibility to infection with sex hormones, hormonal and immunological differences or mechanisms of the sexes (16, 17 and 18). Genderdetermined differences in susceptibility to virus infections have been reported for encephalomyocarditis virus (19). Females are known to mount more vigorous immune responses, especially humoral responses, and in general show higher resistance to bacterial and viral infections (20 and 21).

Even the prevalence and intensity of infections caused by protozoa, nematodes, trematodes, cestodes, and arthropods is said to be higher in males than females, (22). This then raises the possibility of this phenomenon with fungal infections. Animals are not left out in this fact as studies of rodent malaria have illustrated that mortality rates are higher in males compared with females and may involve endocrine and immunological differences between the sex (22).

Males in this study recorded more infection occurring on the head region which comprises of the scalp, face and neck. The females on the other hand recorded their highest site of infection on the limbs (hands and legs). Some of the reasons for the high occurrence of infection on the heads of males could be due to the shortness of their hair, which facilitates easy reach of the fungal spores to the scalp. The frequent shaving of hair from their head and beard from their face by different people, instruments and at different saloons could make them more susceptible to infections. This routine shaving destroys the hydrolipidic film, leading to loss of natural lubrication and protection. This is in complete contrast to females who do more of washing and maintaining of their hair. Another factor could be the less concern the males have about the appearance of their face compared to the females who are very conscious of their face and hair and as such are able to notice and act promptly therefore minimizing infections from their heads, face and neck.

In the case of the females who recorded more infections on their limbs, the reason could be that the female limbs are exposed to damaging environmental elements daily as a result of the nature of their dressings. This is in contrast to their male counterparts whose limbs are mostly covered in trousers and long-sleeved shirts.

This study clearly shows that a higher occurrence of dermatitis is more likely to be seen in males than females for two basic reasons. First is that females are more socially and psychologically conscious of their appearance and so will notice and seek medical advice faster than the males who are likely to not even notice the skin problem on time or when they eventually do, will only seek treatment when there is no other alternative. The second reason is the fragility of the male skin especially on the face as a result of less care of the skin and constant exposure to damaging environmental elements. Although it has been extensively proved that the sex hormones in females whether human or animal make them more resistant to bacterial and viral infections (20 and 21), its application to fungal infections is still to be fully 
studied. This is definitely an area of research that needs further study.

\section{ACKNOWLEDGEMENT \\ REFERENCES}

1 Kwon-Chung, K.J., Bennett. J.E Medical Mycology Lea and Febiger. Philadelphia, Pa. 1992; 105-170

2 Jungerman P.M.F., Schartzman R.M.. Microsporosis and Trichophytosis In Vet.

Medical Mycology. Lea \& Febiger, Philadelphia. 1972; 3-28.

3 Mycology.Reference. Provincial Laboratory for Public Health University of Alberta Hospitals Edmonton , Alberta 2000; http://www.provlab.ab.ca

4 Fatani M.I., Al-Afif K.A., Hussain H. Pattern of skin diseases among pilgrims during Hajj season in Makkah, Saudi Arabia. Int J Dermatol. 2000; 39: 493-.496. PMID: 10940111

5 Ikaraoha C.I, Taylor D.L, Anetor J.I, Igwe C.U, Ukaegbu Q.O, Nwobu G.O, Mokogwu A.T.H.. Demographic Features, Beliefs and Socio-Psychological Impact of Acne Vulgaris among Its Sufferers In Two Towns In Nigeria. Online J Health Allied Scs.; 2005; 4(1): 1 - 6

6 Banerjee B.N., Datta A.K.. Prevalence and incidence pattern of skin diseases in Calcutta. Int J Dermatol; 1973; 12(1): 41- 47. PMID: 4266514

$7 \quad$ Najdawi F., Fa'ouri M. Frequency and types of skin disorders and associated diabetes mellitus in elderly Jordanians. Eastern Mediterranean Health Journal.; 2002; 8(4-5): 5748. PMID: 15603040

8 Johnson M.L., Roberts J. Prevalence of dermatological diseases among person 1-74 years of age: United States. Advance data (from Vital \& Health Statistics of the National Center for Health Statistics, US Department of Health Education and Welfare),; 1977; .4: 17.

9 Rabin B., Fraidlin N..Patients with occupational contact dermatitis in Israel: quality of life and social image. Soc Work Health Care; 2007; 45(2): 97- 111. PMID: 17954445

10 Ekanem, L.S., Gugnani, H.C.. Etiology of dermatophytes amongst school children in Cross River State of Nigeria. Mykosen. 1987; 30:493-498

11 Gugnani, H.C., Onyeka, O.A.. Tinea capitis in School Children in Eastern Nigeria. Mykosen. $1986 ; 29 ; 132-144$

The authors wish to acknowledge Mr. Bulus Datok, Mrs M. Nanza and Miss S. Yusfu for their technical assistance.

12 